\section{Implementing integrated reporting to disclose intellectual capital in health organisations: a case study}

Integrated reporting in health organisations \author{
Department of Economics and Business Studies, University of Genova, Genova, Italy
}

Renata Paola Dameri and Pier Maria Ferrando

\begin{abstract}
Purpose - The aim of our research is to give empirical and theoretical solutions to some criticalities of the original International Integrated Reporting Framework (IIRF). Indeed, it takes as value creation only the increase of the capitals triggered by business activities, overlooking the fulfilment of the institutional mission that is the actual value creation lever.

Design/methodology/approach - The present paper introduces a case study aimed at implementing the IIRF in an Italian non-profit healthcare organisation. The research is based on theory building from cases, action research and interventionist approach. IIRF was adopted because of its claimed ability to support the communication process to stakeholders and the control of value creation. However, IIRF shows several weaknesses.

Findings - An adjusted version of IIRF is suggested, highlighting the role played by IC in the organisational business model and in the value creation process. The adjusted seems able to foster awareness of the role IC in value creation in healthcare organisations.

Research limitations/implications - In this paper no one of the singles pieces of the adjusted framework is innovative by itself, but jointly they give raise to an innovative solution, able to address the disclosing and managerial needs of the examined organisation. The single case study permits to us to test the weaknesses of the IIRF claimed in the literature, to suggest some adjustments to the original framework and to validate their effectiveness. Thanks to the single case study we then built theoretical constructs developing theory inductively; now the suggested framework can be further tested and validated in other organisations.

Originality/value - The paper introduces an innovative approach to IC reporting and disclosure in healthcare organisations. This is relevant not only for external communication but also for internal aims supporting managers in decision and actions.
\end{abstract}

Keywords Health care, Nonprofit organisations, Intellectual capital, Stakeholder analysis, Integrated reporting

Paper type Research paper

\section{Introduction}

A new trend in intellectual capital (IC) reporting and disclosure arises from the International Integrated Reporting Framework (IIRF) (Abhayawansa et al., 2019), a recently issued model (2011, www.integratedreporting.org) supporting organisations in preparing and disclosing integrated documents about performance, strategy and value creation (International Integrated Reporting Council, 2016). Thanks to the framework, companies and organisations can follow a well-defined schema that is flexible enough to be adapted to different situations (Reuter and Messner, 2015).

IIRF puts at its core a business model based on the role that six different capitalsfinancial, manufactured, intellectual, human, social and relational, natural-both tangible and intangible, play in value creation. It therefore considers IC and its components like

(C) Renata Paola Dameri and Pier Maria Ferrando. Published by Emerald Publishing Limited. This article is published under the Creative Commons Attribution (CC BY 4.0) licence. Anyone may reproduce, distribute, translate and create derivative works of this article (for both commercial and non-commercial purposes), subject to full attribution to the original publication and authors. The full terms of this licence may be seen at http://creativecommons.org/licences/by/4.0/legalcode
Received 31 January 2020 Revised 11 May 2020 29 June 2020

Accepted 14 July 2020

\section{Accepted 14 July 2020}


strategic sources of value generation and aims to define how business processes can create value thanks to these capitals (Cheng et al., 2014).

The case study presented in this paper originates from an action research study aimed at implementing IIRF in the Italian non-profit healthcare organisation Associazione Gigi Ghirotti. IIRF was adopted because of its claimed ability to support not only the communication process to stakeholders but also the control of value creation over time, supporting management policies and decisions (Adams, 2015; Dumay et al., 2019). Moreover, IIRF was supposed to be a reporting tool useful in disclosing organisations' business models, particularly IC and its role as a value creation lever (Badia et al., 2019; Camodeca et al., 2019).

Nevertheless, in its implementation there were some challenges due to the non-profit features of Associazione Gigi Ghirotti, with particular regard to its value creation processes. Actually, IIRF takes as value creation only the increase of the capitals triggered by business activities, overlooking the fulfilment of the institutional mission that is the actual value created by a non-profit organisation (Adams and Simnett, 2011; Dameri and Girella, 2019).

On the other hand, previous IIRF experiences in Italian assistance and healthcare organisations have highlighted that the framework can have a slavish implementation, thus preventing an integrated thinking process and effective organisational change. Three experiences are known and have been studied: Cara Mineo, an organisation providing refugees with shelter and assistance; Istituto Giannina Gaslini, a scientific paediatric institute providing hospitalisation and treatments for children's diseases; and the Ancona University Hospital. Each of these shows some of the weaknesses of IIRF in disclosing how organisations produce value and the role of IC in value creation.

Motivation and objective of the present work is to face IIRF's weaknesses in explaining the value creation process and how IC contributes to it (Dumay et al., 2017). An adjusted version of IIRF is suggested, highlighting the role played by IC in the organisational business model and in the value creation process.

The original contribution of this case study to the extant literature about IC in healthcare organisations does not lies on reporting another experience, nor the case study entails a new IC framework; it novelty rather lies in the adjusted reporting that enables to highlight what value or values a healthcare organisation delivers (its outcomes), for whom (its stakeholders) and how (its specific business processes) within a business model effectively connecting them.

In other words the adjusted IIRF enhances theoretical contributions not previously considered, making possible a better understanding of the organisation business model and its value creation; moreover it provides a sound basis for effectively linking theory and practice.

From this point of view, the adjusted IIFR on the one hand mirrors organisations as systems of resources, tangible and intangibles, creating value in terms not only of increased capitals but also of satisfying stakeholders' needs and expectations according to their mission and business models. On the other hand, fostering awareness of the organisation business model and value creation processes, it actually enables integrated thinking and management (Guthrie et al., 2017) as well as a better disclosure to stakeholders, communities and public institutions.

The adjusted IIRF is theoretically consistent and promising for the practice; moreover, given IIRF's flexibility, it appears to be widely applicable in both non-profit and for-profit organisations (Sukhari and De Villiers, 2019). Nevertheless, it is the outcome of only a case study, and it needs to be further tested to consolidate the results.

This paper is organised as follows: the next section analyses the state of the art and the theoretical background of IC and IC disclosure in healthcare organisations and the use of IIRF to disclose IC. Section 3 describes the research methodology, and Section 4 introduces the case study and discusses the findings. Section 5 closes the paper with some remarks about limitations and implications of the present work for both research and practice. 


\section{Literature review and theoretical framework}

The present work is rooted in four theoretical streams: IC, integrated reporting (IR), value creation theory and business processes. In the following three sections, a literature review about these four streams is reported, and in Section 2.4 a theoretical framework based on these streams is suggested, closing with the definition of two research questions also addressing weaknesses emerging from previous IIRF implementations in health organisations.

\subsection{IC in health care: a long journey still in progress}

IC in organisations is a mature topic, born at the end of the twentieth century from the works of Stewart (1997), Edvinsson and Malone (1997), Sveiby (1997), Bontis (1998), Brooking (1998) and Nahapiet and Ghoshal (1998) and rooted in previous works about the role of knowledge and intangible resources in supporting competitive advantage and performance in companies (Hall, 1993; Nonaka et al., 1996; Teece, 1998).

Concurrently with the emerging research stream about IC in companies, IC in health has been studied since the end of the twentieth century. However, at the beginning, IC in health was conceived as the skills and competences shown by physicians and nurses (Robinson, 1998; Sorrells-Jones and Weaver, 1999). Somehow the idea of a "capital", overcoming the simple knowledge of individuals, emerged from some seminal works, especially when addressing the collective competences of health workers (Korhonen and Paavilainen, 2002; Starc, 2009) or linking human capital in health organisations with human resources strategies (Collins and Collins, 2007; Thomka, 2007). Moreover, pioneers such as Schwartz and Pogge (2000) and Covell and Sidani (2013) understand that IC in health organisations (also conceived as human capital) can be an effective lever to improve outcomes and performance. However, this stream of research often cannot link workers' skills with a wider vision about the strategic role that IC could play in a knowledge-intensive sector like health care (Peng et al., 2007; Leal et al., 2019).

Other researchers, such as Peng and Lee (2005) and Li et al. (2019), investigate the specific link between IC, its management and outcomes in health organisations, especially hospitals. Some of these works are based on interviews about the perceptions of physicians and health managers about how IC can support better outcomes. Other studies are based on literature reviews (Leal et al., 2019) or design theoretical models to represent IC in health institutions (Pirozzi and Ferulano, 2016).

A different vision began to arise after 2010, for example, in Hunt et al. (2011), Radaelli et al. (2011) and Carlucci and Schiuma (2012), when IC in health care was finally conceived as an organisational lever: workers' skills came to be seen as part of IC supporting innovation, knowledge sharing became more important than knowledge itself and organisational climate became an engine of IC creation and exploitation. Some researchers, such as Galvan et al. (2012), Erickson and Rothberg (2013) and Hassan et al. (2015), address the topic of IC as a strategic weapon for healthcare organisations, and the problem of identifying, inventorying, measuring and reporting IC emerges, especially posing questions about the link between IC management activities and value creation processes in health care (Vishnu and Gupta, 2015; Mazzotta, 2018).

The most interesting works are those that investigate peculiarities of IC in health care and study the specific configuration IC assumes in this sector and how it can support better performance and value creation processes in such a particular context (Wong and Wickramasinghe, 2014; Miller, 2015; Dameri and Ricciardi, 2015). Overall, it becomes clear that there is a specific value chain linking knowledge management in health organisations, IC management and performance. Serenko and Bontis (2004) and Sibbald et al. (2016) conceive knowledge as the most important IC component, and knowledge management enhances organisational learning flows, supporting knowledge development and sharing and forming in turn both human capital and relational capital (Galvan et al., 2012; Hassan et al., 2015).

The gap emerging from the extant literature is that, although the vision moved from IC as individual skills and competences towards IC as a lever for better management of healthcare
Integrated reporting in health organisations 
JIC

22,2

\section{4}

organisations, a comprehensive theoretical and empirical vision of how IC plays a pivotal role in a health organisation's processes and in the value creation stream is still lacking.

\subsection{IC reporting and disclosure and IIRF}

Despite 20 years of research and studies about IC in organisations, IC reporting is still a problem (Chiucchi et al., 2016; Zambon and Dumay, 2016). Even some pioneer companies adopting IC reporting (such as Skandia) have recently abandoned this accounting practice. The Danish IC Guidelines have been unused (Danish Ministry of Science Technology and Innovation, 2003), and IC reporting is sometimes considered irrelevant (Schaper et al., 2017) or unable to play any role for business (Mouritsen and Roslender, 2009; Fincham and Roslender, 2003).

Several scholars, such as Schaper et al. (2017) and Dumay (2016), also basing their assumptions on empirical investigations and interviews with managers, suggest abandoning IC reporting and moving towards IC disclosure, adopting more significant instruments and practices to let stakeholders better understand how an organisation takes into consideration ethical, social and environmental impacts, overcoming IC reporting weaknesses in creating an understandable communication channel with stakeholders (Feng et al., 2017).

In this stream, some researchers, such as Adams (2015) and Abhayawansa et al. (2019), recently individuated in IIRF a new model able to revitalise IC reporting and disclosure for several reasons.

First, as can be seen in Figure 1, IIRF is explicitly based on the role that six capitals (financial, manufactured, intellectual, social and relational, human and natural) have in producing value through the business model adopted by a company or organisation. Even if based on all types of capitals, intangible capitals have an important role and are interconnected with tangible and financial capitals (a strength of IIRF). Abhayawansa (2014) and Garanina and Dumay (2017) see this as the basis for an integrated reporting focussed on integrated thinking about a company, its assets and value creation.

Moreover, Beattie and Smith (2013) and Sukhari and De Villiers (2019) observe that IIRF links capitals with each other and with the business model adopted by a company or organisation, and it gives an interpretative framework for the role that IC and other capitals play in value creation. It also integrates in a unique disclosure document some non-financial

Figure 1.

The International Integrated Reporting Framework

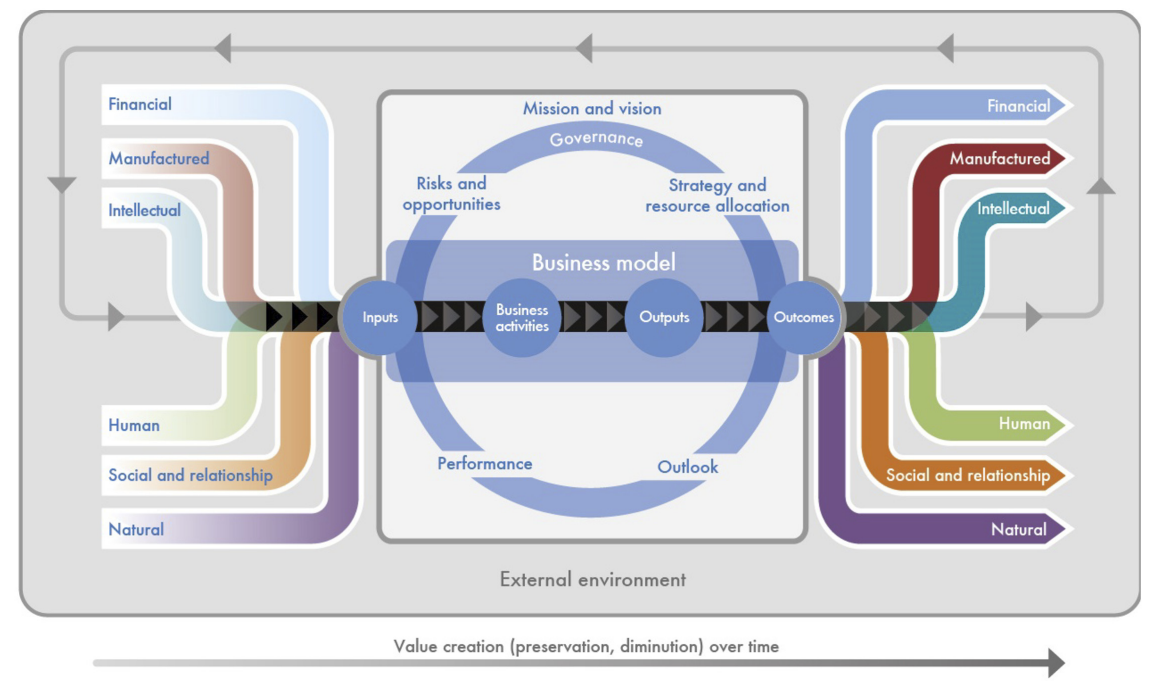


aspects that are acquiring more and more importance for companies, such as corporate social responsibility and sustainability, linking them also to IC (De Villiers and Marques, 2016).

For IC disclosure in health care, IIRF could also be a useful tool because it focuses on human capital and social and relational capital, considered by the literature as the most important intangible resources for healthcare entities (Covell and Sidani, 2013; Pirozzi and Ferulano, 2016; Cavicchi, 2017). IIRF also links capitals with mission and vision in a visual and explicit way, supporting the strategic view of IC in healthcare entities (Elton and O'Riordan, 2016).

Regarding IC disclosure in the non-profit sector, it must be said that IIRF was conceived for for-profit companies; however, as it emerges in the works of Adams and Simnett (2011) and Dameri and Girella (2019), IIRF shows several strengths that make it applicable also for non-profit organisations, even if the topic has been under-investigated until now. Thanks to its flexibility, IIRF is able to be adapted to different sectors and contexts. As it is based on non-financial measurement, it can capture the social, moral and ethical values underpinning non-profit business models and aims, as well as those of the healthcare sector.

Surely, IIRF also has several limitations affecting its efficacy in disclosing IC and value creation. Several authors, such as Dumay and Garanina (2013), Feng et al. (2017), Dumay and Roslender (2013) and Demartini et al. (2015), outline how IR, even as it is increasingly used by companies worldwide, is still immature and inadequate to clearly disclose the links between IIRF, firms' business models, created value and the capability of the organisation to use IC to respond to the expectations of shareholders and stakeholders (Dumay and Garanina, 2013; Feng et al., 2017; Dumay and Roslender, 2013; Demartini et al., 2015). Moreover, empirical evidence that IR will improve IC reporting is provided only for the for-profit sector (Terblanche and De Villiers, 2019), and no studies are available about IR effectiveness in disclosing IC and its role in creating value in the healthcare sector.

The gap emerging from the extant literature shows that no studies are available about the use of IIRF to disclose IC in health organisations, despite several premises emerge about the suitability of this instrument to the health sector features.

\subsection{Business processes and value creation}

As regards business processes, the main framework proposed to analyse the business activities for value creation is the Value Chain model introduced by Michael Porter (1985) to highlight the drivers of competitive advantage. Nevertheless, Porter's value chain is not effective in capturing IC as a value driver. Therefore, this paper adopts a reshaped version of the Value Chain (Donna, 1992) to better describe this aspect.

The reshaped Value Chain classifies business activities into three kinds of processes:

(1) Direct processes, providing customers and users with valuable products.

(2) Indirect processes, supporting the direct processes with resources and services enabling them to supply valuable products.

(3) Supporting processes, building the basis the organisation depends on for its future.

The mainstream theories about value creation can be summarised in Shareholder Value Theory (Rappaport, 1986) and Stakeholders Theory (Freeman, 1984), both focussed on forprofit organisations.

While Rappaport focuses on the shareholders' value, assuming that the only organisational aim is to meet the shareholders' expectations, Freeman stresses the stakeholders' relevance, defining them as "those groups who can affect or are affected by the achievement of an organisation purpose" (Freeman, 1984, p. 49).

Stakeholders theory makes evident the biunique relation connecting a company to its stakeholders and assumes that stakeholder value creation is a condition for shareholder value creation (Freeman, 1984; Harrison and Wicks, 2013; Rusconi, 2019).
Integrated reporting in health organisations 
JIC

22,2

\section{6}

Besides these mainstream theories, a different approach to value creation focussing on stakeholder value is suggested by another relevant literature stream addressing nonprofit organisations. It was developed by scholars and institutions engaged in focussing on the social enterprise value creation through the Impact Value Chain Model (IVCM) (GECES Social, 2014; Hehemberger et al., 2015). This model is a framework highlighting that a venture activity leads to its desired outcomes and impact thanks to a five-step sequence: inputs, activities, output, outcome, social impact. Within this chain, outputs are the countable and measurable units of production yielded by the organisation, outcomes are the effects resulting in terms of benefits engendered in the stakeholders' well-being, and social impacts are the ultimate permanent changes made in society that are attributable to an organisation's activities. The Impact Value Chain Model (IVCM) also considers the benefits delivered to the stakeholders as value created by the organisation.

The IVCM can be easily adopted in health organisations, both public and private, forprofit and not-for-profit. Indeed, the value created and delivered by health organisations is a social value, pursuing the final outcome of health.

IIRF deviates from the mainstream value creation theories because, differently from Rappaport, it considers as value creation not only the increase of shareholder capital but also the increase of the other capitals the organisation uses; moreover, differently from Freeman, it does not take into account the stakeholders' value.

\subsection{Theoretical framework and research questions}

The theoretical framework at the basis of the present paper stands at the crossroads between IC in health care, value creation theory, business processes for value creation and IIRF as an effective model to disclose IC:

(1) Value creation is the aim, and it should be considered as not only the increase of capitals but also the outcomes of health organisations, as defined by the IVCM.

(2) IC is the strategic and organisational lever for value creation; however, it should be analysed in business processes as classified by the reshaped value chain to reveal its role and contribution.

(3) Business processes are the specific way each health organisation, and, more generally, each organisation tout court, exploits and manages IC to create value, and they should be revealed (not concealed, as they are in IIRF).

(4) IIRF is the disclosing instrument, but, given its theoretical and applicative weaknesses, it requires some adjustments to be effective.

Given the gaps emerging from the extant literature, two research questions are defined:

$R Q 1$. Is IIRF able to highlight an organisation's business model and how IC plays as a lever of value creation?

RQ2. Can IIRF actually foster integrated thinking and enable proactive management practices?

Moreover the relevance of these questions is confirmed by the analysis of previous experiences in implementing IIRF in Italian healthcare organisations.

(1) The 2016 Integrated Report by Cara Mineo, an organisation providing refugees with shelter and assistance, reports as outcomes the impact its activity has made on the IIRF six capitals, including the refugees satisfaction within the Relational and Territorial Capital (https://ita.calameo.com/read/005711392c1213932b543). 
(2) The 2015-2016 Integrated Report issued by Istituto Giannina Gaslini, a scientific paediatric institute providing hospitalisation and treatments for children's diseases, in addition to five of six capitals, discloses its Social Return on Investment (SROI) as a measure of created value (http://www.gaslini.org/wp-content/uploads/2017/10/ REPORT.pdf).

(3) The 2018 Integrated Report by the Ancona University Hospital takes as the outcome of its value creation process the six capitals variations and a final outcome corresponding to its institutional mission, defined as "fulfilment of health need". The final outcome is presented through two dense lists of performance indicators (http:// www.ospedaliriuniti.marche.it/portale/).

From this analysis, it emerges that IIRF is considered inadequate and incomplete for healthcare organisations as it lacks perspective regarding the stakeholders' satisfaction and the fulfilment of the organisational mission. Indeed, each case, in adopting IIRF, integrates the model with further indicators. However, it also emerges that the framework has been applied in an uncritical way, failing to produce an effective integrated thinking. All these reports appear as descriptive documents: no suitable idea of created value is adopted, and no relation between IC and created value is pointed out to highlight the current business model and the value creation drivers. Implementing IIRF in this way does not make it possible to base the value creation practice on a reliable theoretical model. From this point of view, Guthrie et al. (2017) observe that by itself, IIRF adoption may trigger only formal changes; to actually affect organisational behaviour, IIRF implementation should be supported by specific internal mechanisms like crossfunctional teams, innovative measurement systems, education and participation. In other words, by these means, knowledge management and organisational learning processes have to be started in order to foster a wide and deep sharing of a business model, enabling integrated thinking, organisational change and proactive management. It is reasonable to imagine that these mechanisms run better when combined with an adjusted IIRF, creating awareness of how the business processes actually connect capitals, shareholders and value creation.

\section{Research methodology and case study}

\subsection{Methodology}

This paper is based on theory-building from cases, action research and an interventionist approach.

Building theory from case studies is a research strategy that involves using one or more cases to create theoretical constructs, thanks to case-based, empirical evidences (Eisenhardt, 1989). Theory can be built using a case study as an experiment from which to develop theory inductively (Eisenhardt and Graebner, 2007).

Action research is a research strategy that seeks transformative change by doing research and taking action concurrently (Lewin, 1958; Stringer, 2013). It aims at reflecting upon the consequences of actions to understand, develop and improve social and managerial practices (Burns, 2007).

The interventionist approach (Dumay, 2011) is especially suitable when a complex phenomenon emerges and requires concrete solutions when it has not been theoretically studied; it is motivated by the fact that one of the researchers has been involved with the investigated organisation to cooperate in the development of the integrated reporting for the Gigi Ghirotti Association, a non-profit health organisation. This has afforded the researcher the opportunity to use hands-on experiments (Jönsson and Lukka, 2007) and to move in and 
JIC
22,2

318

out of the organisation, sharing with the other researcher the evidence arising from the research to develop theoretical insights (Chiucchi et al., 2016).

The research is based on a single case study; it is justified because the researchers had unique and rich access to first-hand data and observations (Yin, 1994). This made possible to carry out an in-depth analysis focusing the organisation context and processes, taking advantage of a set of different concepts and models theoretically grounded and suggesting an adjusted version of IIRF able to bridge the gap between empirical evidence and the theoretical framework. The emerging theory arises from a unique occasion to directly explore a significant phenomenon, and it is accurate and testable (Scuotto et al., 2016). It permits the further application of the suggested theoretical model to validate the results of the present research. The findings generalisation should be understood, accordingly to Hellström (2008), as the possibility of applying results obtained in the case study to similar non-profit health organisations, but also as the preliminary steps to build a general modification of IIRF applicable to all the organisations adopting it.

The interventionist researcher might not be neutral, and the research could be flawed by bias (Jönsson and Lukka, 2007; Dumay, 2011); in the present case, the interventionist researcher was joined by another author who cooperates as an external observer and discussant (Jakkula et al., 2006). Thanks to their collaboration, the researchers were able to cross the border between the emic (insider) and etic (outsider) perspectives and overcome the non-neutral nature of the interventionist approach (Jönsson and Lukka, 2007).

The adopted methodology is organised in three steps:

(1) The first step consists of studying the state of the art in extant literature and in collecting empirical evidence about IIRF implementation in health organisations by analysing the integrated reporting of Cara Mineo, Istituto Giannina Gaslini and the Ancona University Hospital (see Section 2.4), evidencing the weaknesses of both the theoretical framework and its empirical implementations.

(2) The second step takes action about the implementation of IIRF in the Gigi Ghirotti Association (GGA), collecting and analysing evidence.

(3) The third step consists of reflecting about the emerging issues, sharing them both with the GGA governance and management bodies and among the action researchers, and suggesting behavioural and managerial changes (Lewin, 1958).

\subsection{Case study}

As already pointed out, this paper is based on a single case study of the GGA. GGA is a nonprofit, middle-size healthcare organisation established in Genoa in 1984. It provides terminal cancer, HIV and ALS patients with palliative treatments and assistance, supporting parents and relatives, too. Its services are provided at home and in hospice thanks to two premises the Association owns in town. GGA is a well-known, very highly regarded entity that plays a pivotal role in the local area, satisfying health needs and expectations that would otherwise remain unfilled. The following data and information can well explain its size and complexity (Ferrando, 2019). Over the three-year period from 2016-2018, the number of GGA patients increased as follows (see Table 1):

Table 1.

\begin{tabular}{lcc}
\hline & At home & In hospice \\
\hline 2016 & 2387 & 486 \\
2017 & 2325 & 492 \\
2018 & 2431 & 510 \\
\hline
\end{tabular}


The GGA staff includes both employees and voluntary workers. Employees in turn include both wage-earning employees and professionals by contract of services (see Table 2).

GGA revenues come from fees from the National Health Service (NHS) local agency, fundraising and charitable contributions (values in $€$ ) (see Table 3).

While the fees from NHS stay steady over the period of investigation, the revenues from fundraising and charitable contributions are quite variable, proving to be a relevant condition the Association depends on for its continuity over time (see Table 4). It is not by chance that their trend directly affects the profit and loss account, being the net income positive or negative accordingly with their amount (values in $€$ ).

In any case, the association benefits from sound assets and equity endowment (see Table 5), assuring it a steady prospect (values in $€$ ).

These data mirror a complex organisation with specific governance and management problems. To face them, GGA developed formal governance bodies and management and administrative structures. The governance of the association is assured according to its Charter by different bodies. First of all, an executive board and a board of external auditors are appointed by the members' meeting. In turn, the executive board appoints the President. Finally, the association adopted an ethical code, proving to consider the soundness of the organisational behaviour an important component of its social role.

The association runs following the targets set by the executive board. A Chief Operating Officer supervises several units responsible for the management of the two hospices, home assistance, pharmacy services, administration, accounting and finance and general affairs. The main internal processes concern the quality system management and the financial accounting system resulting in a formal financial statement.

\begin{tabular}{lccc}
\hline & Wage-earning employees & Professionals by contract of services & Voluntary workers \\
\hline 2016 & 84 & 100 & 250 \\
2017 & 83 & 103 & 270 \\
2018 & 90 & 102 & 300
\end{tabular}

Integrated reporting in health organisations

\begin{tabular}{ccrrr}
\hline & Fees from the NHS & Fundraising and charitable contributions & Total \\
\hline 2016 & $4,207,444$ & $3,283,491$ & $7,490,935$ & \\
2017 & $4,246,930$ & $6,646,262$ & $10,893,192$ & Table 3. \\
2018 & $4,303,555$ & $5,037,101$ & $9,340,656$ & Revenues \\
\hline
\end{tabular}

\begin{tabular}{lcc}
\hline & Net income & \\
\hline 2016 & -471.876 & \\
2017 & 2.722 .393 & Table 4. \\
2018 & 638.283 & Net income \\
\hline
\end{tabular}

\begin{tabular}{lrrr}
\hline & Total assets & Equity & \\
\hline 2016 & 11358351.57 & 8531383.04 & \\
2017 & 14522219.95 & 11253776.35 & Table 5. \\
2018 & 15510574.62 & 11892059.89 & Assets and equity \\
\hline
\end{tabular}


GGA also faces external problems concerning relations with shareholders and the local community in order to make known its outcomes and promote its image. For that purpose, the association has been issuing a social report since 2009.

\subsection{Data collection and analysis}

At the end of 2017, GGA, unsatisfied with the quality and effectiveness of its disclosure to stakeholders, asked the Department of Economics and Business Studies of Genoa University for support in updating and improving its long-standing social report. From this need, a cooperation was born, providing the opportunity to test IIRF implementation for satisfying complex disclosure needs and supporting the internal management of critical resources concurrently.

First, a project team was set up involving both academic researchers and GGA managers. The aim was to study the needs of the association and, through an interventionist approach, support it in realising its improved social reporting, collecting in the meantime evidence and reflections to design a theoretical framework about non-financial disclosure in healthcare organisations.

The team included three academic researchers and three GGA managers:

(1) One interventionist researcher, working inside the organisation.

(2) One discussant researcher, observing from outside the organisation and discussing the results gradually emerging from the action research.

(3) One post-graduate student writing her final dissertation and helping take notes and collect documents.

(4) The GGA CFO.

(5) The GGA COO.

(6) One member of the GGA supervisory board.

The work was organised as a spiral of learn-and-action meetings (Carr and Kemmis, 2003) able to diagnose the problems, plan actions, implement solutions and reflect on outcomes, learning by doing.

The interventionist researcher, the student and the GGA managers attended six GGA meetings to collect data about the case, to discuss solutions and to get feedback about the gradual implementation of the integrated reporting.

The project lasted from July 2018 until April 2019. During this period, data and information were collected. The main sources were the following:

(1) Notes from six meetings involving the GGA members of the research team listed above that were designed to discuss solutions and to obtain feedback about the gradual implementation of the integrated reporting; after each GGA meeting, the interventionist researcher, the student and the discussant researcher attended the academic meetings, seeking to learn from the action taken and to improve the solutions at each cycle.

(2) Semi-structured interviews, addressed to the GGA CFO, COO and member of the supervisory board; questions regarded the aims and mission of the association, internal processes, disclosing documents issued by the organisation, perceived importance of different stakeholders and awareness about critical resources.

(3) Proprietary reports and documents.

Interviews were transcribed and then coded together with additional proprietary text documents, particularly financial and social reporting, and with integrated reporting issued by the other non-profit organisations examined previously. 
The project was completed at the beginning of 2018, and the GGA Integrated Report 2018 was released in spring 2019 (https:/www.gigighirotti.it/wp-content/uploads/2019/05/ integrated-report.pdf). Moreover, GGA is committed to continuing to issue the integrated report regularly in the long term.

\section{Implementing IIRF in GGA: empirical and theoretical findings}

IIRF implementation in GGA began as a way to improve the organisation's social report; however, GGA was not totally clear on how to improve it or on the reasons why its previous versions were unsatisfactory. The following emerged from the unstructured interviews:

(1) GGA felt the need to improve its social reporting, especially to create a better disclosure towards its stakeholders, without being able to suggest how to obtain these improvements.

(2) GGA was aware about the existence of a relationship between stakeholder satisfaction, value creation and delivery, business processes and critical resources, especially intangible resources, but it was unable to describe this relationship.

(3) Although it placed primary importance on some intangible resources such as worker skills, reputation and organisational climate, GGA was not aware about the existence of IC and did not feel the need to report or disclose it.

The choice of IIRF to support GGA social reporting improvement was driven by IIRF features. For the first, IIRF considers value creation as a multi-capital process originating from a range of capitals (inputs) feeding business activities that give rise to specific products (outputs) and result in increasing these capitals (outcomes); therefore, it can support GGA to discover and represent the relations between all these business components. Moreover, it asserts that discovering the interdependences between capitals and business activities is important to highlight the organisation's business model and the value creation process; as a consequence, integrated reporting supports integrated thinking and integrated management, and vice-versa, and encourages the analysis of IC in an integrated way.

During the IIRF implementation, however, several criticalities emerged, confirming the weaknesses detected in the extant literature and in the examples of integrated reporting issued by other healthcare organisations. These criticalities were the trigger to start a deep reflection that led to the suggestion of some adjustments to IIRF. These adjustments can be summarised as follows:

(1) Stakeholders are extracted from the relational and social capital and evidenced as a key element in the business model.

(2) Organisations' performance is extended, adding to the increase of the six capitals the answers to the stakeholders' needs and expectations.

(3) The business model is explicated, including direct, indirect and support processes into the framework.

In the following section, a double path is described: the empirical path compares GGA reporting needs and IIRF criticalities and implements some empirical solutions to obtain the desired reporting effectiveness; the theoretical path reflects on the findings emerging from the empirical path and suggests adjustments to IIRF, supported by the literature and determines if they can be universally applied to non-profit healthcare organisations and beyond.

Table 6 at the end of this section summarises these paths. 


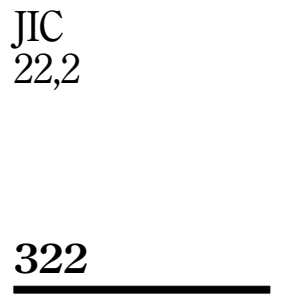

\begin{tabular}{|c|c|c|c|c|c|}
\hline GGA need & IIRF criticality & $\begin{array}{l}\text { Empirical } \\
\text { solution }\end{array}$ & IIRF adjustment & References & $\begin{array}{l}\text { Implications for IC } \\
\text { disclosure in } \\
\text { health }\end{array}$ \\
\hline $\begin{array}{l}\text { Issue better } \\
\text { social reporting, } \\
\text { addressing an } \\
\text { effective } \\
\text { disclosure to its } \\
\text { stakeholders }\end{array}$ & $\begin{array}{l}\text { IIFR takes as } \\
\text { value creation } \\
\text { increases in the } \\
\text { different capitals } \\
\text { a company uses, } \\
\text { overlooking } \\
\text { stakeholder } \\
\text { satisfaction and } \\
\text { not evidencing } \\
\text { the organisation } \\
\text { stakeholders in } \\
\text { the business } \\
\text { model, leaving } \\
\text { them hidden in } \\
\text { social and } \\
\text { relational capital }\end{array}$ & $\begin{array}{l}\text { A deep analysis } \\
\text { of GGA } \\
\text { stakeholders, } \\
\text { classifying them } \\
\text { in primary } \\
\text { stakeholders and } \\
\text { secondary } \\
\text { stakeholders }\end{array}$ & $\begin{array}{l}\text { To highlight the } \\
\text { organisation's } \\
\text { stakeholders as } \\
\text { components of the } \\
\text { business model } \\
\text { instead of leaving } \\
\text { them hidden into } \\
\text { social and } \\
\text { relational capital }\end{array}$ & $\begin{array}{l}\text { Shareholder value } \\
\text { theory } \\
\text { (Rappaport, 1986) } \\
\text { and Stakeholder } \\
\text { theory (Freeman, } \\
\text { 1984; Harrison } \\
\text { and Wicks, 2013; } \\
\text { Rusconi, 2019) }\end{array}$ & $\begin{array}{l}\text { Healthcare } \\
\text { organisations do } \\
\text { not feel the need to } \\
\text { explicitly disclose } \\
\text { IC. These } \\
\text { organisations do } \\
\text { not consider IC as a } \\
\text { comprehensive } \\
\text { asset and manage } \\
\text { single IC } \\
\text { components } \\
\text { The adjusted IIRF } \\
\text { is able to support } \\
\text { healthcare } \\
\text { managers to better } \\
\text { understand IC, its } \\
\text { role and its value }\end{array}$ \\
\hline $\begin{array}{l}\text { Issue a clear } \\
\text { report able to } \\
\text { demonstrate the } \\
\text { value created for } \\
\text { the stakeholders }\end{array}$ & $\begin{array}{l}\text { IIRF considers } \\
\text { the performance } \\
\text { of a business } \\
\text { model only in } \\
\text { terms of } \\
\text { increased } \\
\text { capital, } \\
\text { neglecting non- } \\
\text { financial } \\
\text { outcomes }\end{array}$ & $\begin{array}{l}\text { Considering two } \\
\text { levels of analysis: } \\
\text { the amount and } \\
\text { the quality of the } \\
\text { most relevant } \\
\text { capitals and the } \\
\text { fulfilment of the } \\
\text { primary and } \\
\text { secondary } \\
\text { stakeholders' } \\
\text { expectations }\end{array}$ & $\begin{array}{l}\text { Extending the } \\
\text { organisation's } \\
\text { performance } \\
\text { disclosed in the } \\
\text { integrated report, } \\
\text { adding to the six } \\
\text { capitals increase } \\
\text { the answers to } \\
\text { stakeholders' } \\
\text { needs and } \\
\text { expectations } \\
\text { using appropriate } \\
\text { KPIs }\end{array}$ & $\begin{array}{l}\text { The impact value } \\
\text { chain model } \\
\text { (Hehemberger et } \\
\text { al., 2015; GECES } \\
\text { Social, 2014) }\end{array}$ & $\begin{array}{l}\text { In health } \\
\text { organizations, IC is } \\
\text { particularly } \\
\text { important both to } \\
\text { achieve non- } \\
\text { financial outcomes, } \\
\text { and for its capacity } \\
\text { to regenerate the } \\
\text { used capitals. The } \\
\text { adjusted IIRF, } \\
\text { gives a specific } \\
\text { place to } \\
\text { stakeholders in the } \\
\text { model }\end{array}$ \\
\hline $\begin{array}{l}\text { A clear under- } \\
\text { standing of how } \\
\text { the business } \\
\text { processes create } \\
\text { value, } \\
\text { connecting the } \\
\text { six capitals, } \\
\text { especially the } \\
\text { intangible ones, } \\
\text { to their } \\
\text { outcomes }\end{array}$ & $\begin{array}{l}\text { IIRF neglects to } \\
\text { consider in detail } \\
\text { what an } \\
\text { organisation } \\
\text { does to create } \\
\text { value }\end{array}$ & $\begin{array}{l}\text { The GGA value } \\
\text { chain is defined, } \\
\text { evidencing } \\
\text { which key } \\
\text { processes create } \\
\text { value and how } \\
\text { they impact GGA } \\
\text { performance }\end{array}$ & $\begin{array}{l}\text { Reshaping the } \\
\text { business } \\
\text { processes as } \\
\text { suggested by } \\
\text { IIRF, including } \\
\text { direct, indirect } \\
\text { and support } \\
\text { processes in the } \\
\text { framework }\end{array}$ & $\begin{array}{l}\text { Porter's value } \\
\text { chain (1985) and } \\
\text { the reshaped } \\
\text { value chain model } \\
\text { (Donna, 1992) } \\
\text { reclassifying } \\
\text { business } \\
\text { processes (direct, } \\
\text { indirect, and } \\
\text { support } \\
\text { processes) }\end{array}$ & $\begin{array}{l}\text { In health } \\
\text { organisations, } \\
\text { performance } \\
\text { should be } \\
\text { considered in a } \\
\text { broad sense, } \\
\text { especially } \\
\text { considering non- } \\
\text { financial outcomes, } \\
\text { and it is even true } \\
\text { in non-profit health } \\
\text { organisations } \\
\text { The adjusted IIRF, } \\
\text { giving a specific } \\
\text { place to } \\
\text { stakeholders in the } \\
\text { model, overcomes } \\
\text { this limitation }\end{array}$ \\
\hline
\end{tabular}

\subsection{The need to communicate to stakeholders: first IIRF adjustment}

As with any kind of organisation, GGA exists to create value to meet its stakeholders' needs and expectations (Donna, 1999, p. 25). GGA expressed its first need as the desire to issue better social reporting, addressing an effective disclosure to its stakeholders. However this outlined a first criticality, as IIFR takes as value creation increases in the different capitals a company uses, overlooking stakeholder satisfaction and not evidencing the organisation stakeholders in the business model, leaving them hidden in social and relational capital. 
The deviation of IIRF from the mainstream value creation concepts remains hidden as long as the framework is implemented within for-profit organisations. In this case, increases in financial capital (or, rather, in the equities) could be considered a proxy of the fulfilment of the shareholders' expectations. On the contrary, when IIRF is implemented in non-profit organisations, there is no profit and there are no stakeholders taking benefits from profits. In these organisations, the financial capital is no more pivotal, even if it has always to be preserved in order to maintain the organisation continuity. The value creation process aims foremost at achieving social performances aligned with the organisation's mission.

To face the misalignment between GGA's disclosure needs and IIRF's criticality, an empirical activity was suggested to carry out a deep analysis of GGA stakeholders, identifying them by answering to the following questions: what kind of value does the organisation create? For whom is this value created? Who are the organisation's stakeholders? As regards GGA, these questions can be answered referring to the mission summarised in the main organisation purposes:

(1) To provide patients with high-quality services, supporting their families as well.

(2) To play a top-level role in the local context, fulfilling needs and expectations otherwise unfilled.

These purposes permit to identify the organisation primary and secondary stakeholders differently from some other current classifications.

Primary stakeholders are patients and their families. Their needs and expectations are at the core of GGA's mission.

Secondary stakeholders are:

(1) Volunteers and donors providing unpaid labour and financial resources and expecting to satisfy their philanthropic motivation by cooperating with a worthy cause.

(2) Staff (employees and professionals) expecting the opportunity to do jobs rewarding from the professional and human points of view.

(3) The Liguria Region and the local Health Service Agency as representatives of the National Health Service, expecting the implementation of high-quality and nonsubstitutable services on the basis of specific agreements.

They provide the organisation with contributions, legitimacy and consensus critical for its future and their needs and expectations have to be fulfilled in order to maintain their cooperation over time.

The empirical solution, supported by the theoretical reflections about value creation theories, suggests a first IIRF adjustment.

A1. To highlight the organisation's stakeholders as components of the business model instead of leaving them hidden into social and relational capital and to classify them into primary and secondary stakeholders (see Figure 2).

\subsection{Demonstrating the created and delivered value: second IIRF adjustment}

The second need expressed by GGA was to issue a clear report able to demonstrate the value created. In comparing this need with IIRF, a second criticality emerged as IIRF considers the performance of a business model only in terms of increased capitals, neglecting non-financial outcomes. In particular increasing capitals should rather be considered as a condition to improve organisation sustainability while the outcomes produced fulfilling the stakeholders' needs and expectations are the actual value creation.
Integrated reporting in health organisations 


\section{$\mathrm{JIC}$ 22,2}

\section{4}

Figure 2.

The first adjustment of IIRF: stakeholders are introduced into the business model

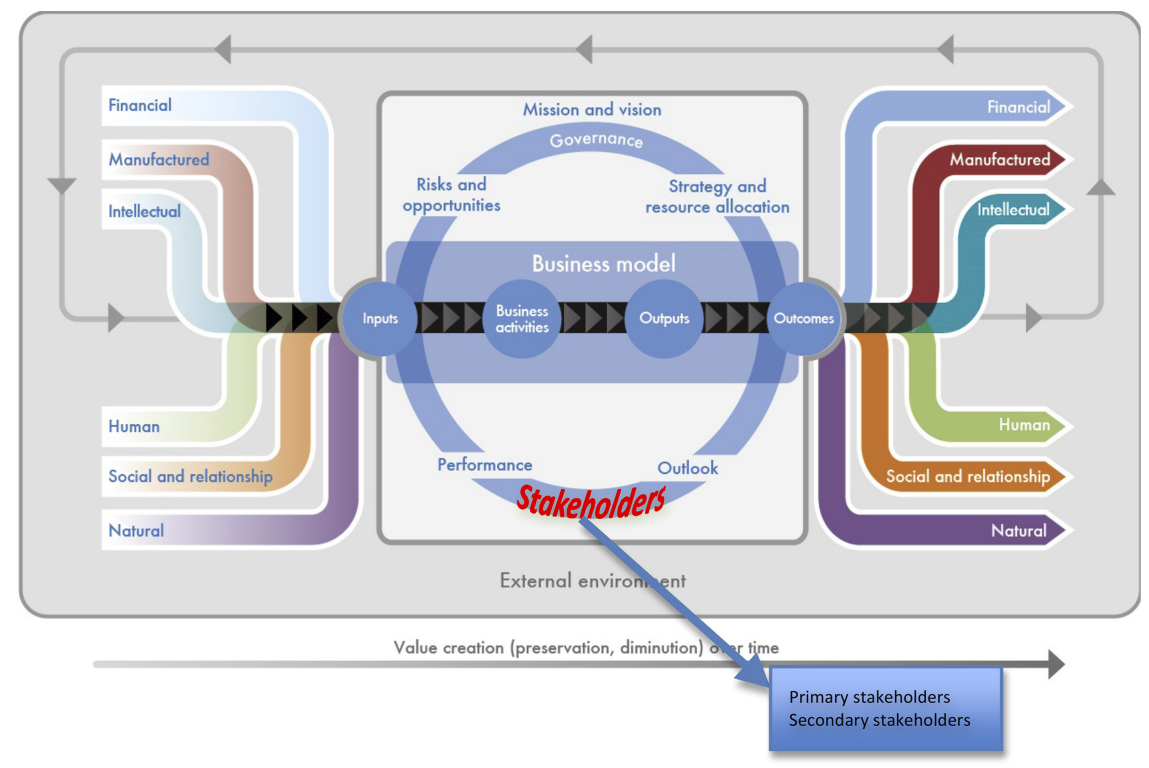

The empirical solution suggested and implemented by GGA was to take advantage of the IVCM, considering two levels of analysis: the amount and the quality of the most relevant capitals and the fulfilment of the primary and secondary stakeholders' needs and expectations.

The first level of analysis addressed the most relevant GGA capitals, considered as success factors for the organisation's performance and the ones most connected with the health/non-profit nature of this organisation:

(1) Human capital: staff and volunteers considered according to their duties and competences.

(2) Organisational capital: operating procedures and, in particular, the quality management system.

(3) Social and relational capital: image and reputation.

All these capitals are intangibles belonging to the category of IC. Regarding the other capitals mentioned by IIRF, financial capital plays an important but not critical role. Manufactured and natural capitals at present do not pose critical problems. About the amount and nature of capitals in GGA, financial and manufactured capitals are financial or market values or quantitative and measurable data. Human, organisational, social and relational capital are intangibles to be monitored by quantitative data with financial values acting as indirect indicators of immaterial values. GGA records show an ongoing reproduction of the used capitals, ensuring continuous service delivery.

The second level of analysis addressed the fulfilment of the primary and secondary stakeholders' needs and expectations. Regarding primary stakeholders, their satisfaction is measured through the perceived quality surveys of in-house and at home services. Regarding secondary stakeholders, satisfaction is measured through the following: 
(1) The level and continuity of volunteer flows, taken as a proxy of their satisfaction with the work at GGA.

(2) The level and continuity of grants, taken as a proxy of GGA's image and reputation.

(3) The number of controversies with staff, taken as a proxy of the organisational climate.

(4) The disputes with health service agencies, taken as a proxy of institutional compliance.

In this regard, GGA records show a perceived high and steady quality of delivered services by primary stakeholders and a strong and steady commitment by the secondary stakeholders. All of this in turn engenders a positive image of the organisation as an important social player able to positively contribute to the common good.

It is worth noting that the control of the outcomes meant both as variations in the value of the capitals and as stakeholder satisfaction is quite challenging. Intangibles are immaterial values preventing quantitative measurement. Stakeholder satisfaction is a complex qualitative value depending on tangible and intangible factors (Harrison and Wicks, 2013, p. 109). As a consequence, the described Key Performance Indicators (KPIs) should be possibly integrated by some narrative able to improve the information quality: KPIs validate the narrative by objective references and narrative provides KPIs with a framework useful to better appreciate them.

The empirical findings suggest a second adjustment to IIRF.

A2. Extending the organisation's performance disclosed in the integrated report, adding to the six capitals increase the answers to stakeholders' needs and expectations using appropriate KPIs.

In other words, the second adjustment considers both the increase of the capitals and the stakeholders' satisfaction as different but connected components of the created value. This adjustment is designed into the framework as it emerges from Figure 3.

\subsection{Connecting value creation, IC and business processes: third IIRF adjustment}

A third criticality met in implementing IIRF in GGA regards the need to have a clear understanding of how the business processes create value, connecting the six capitals, especially the intangible ones, to their outcomes. In this case, comparing GGA's needs with IIRF reveals a criticality because IIRF neglects to consider in detail what an organisation does to create value. In IIRF, business processes are like a black box: they do not analyse the activities an organisation runs to transform capitals into outputs and outcomes. In particular, they do not classify them to highlight the drivers of value creation, hiding how IC affects and is affected by business activities. Moreover, it does not highlight the resources an organisation needs to effectively run its activities. Consequently, IIRF risks an uncritical implementation that is unable to foster integrated thinking processes.

This aspect is important for at least two reasons. The first one is that processes are the missing link between value creation, stakeholders and capitals: defining them allows the disclosure of the cause-effect relation linking all these business components. The other reason is that without a clear understanding of these relations the capability to strategically handle IC is negatively affected.

To face this third weakness of IIRF, the GGA value chain is defined, evidencing which key processes create value and how they impact GGA performance, taking advantage of the reshaped version of the value chain.

The GGA business activities can then be classified as follows: 
JIC

22,2

326

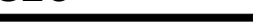

Figure 3.

The second adjustment of IIRF: organization performance include stakeholders'

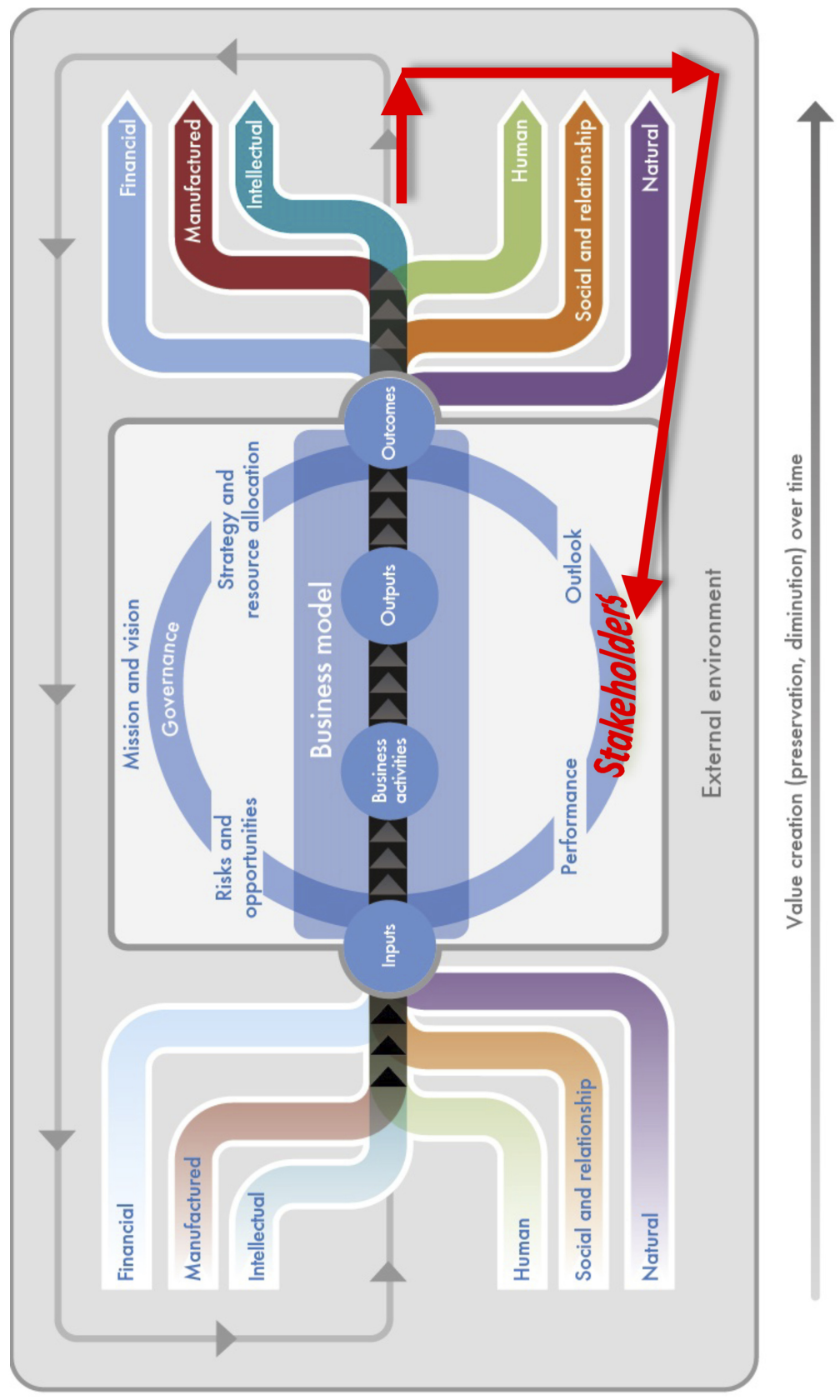
satisfaction 
(1) Direct processes, regarding assistance delivery at home and in hospice.

(2) Indirect processes, regarding human resources management and quality system management.

(3) Supporting processes, regarding development and innovation, communication and fund-raising.

The GGA value creation processes and their drivers and critical interdependences can be shown through an integrated model as in Figure 4.

GGA's capability to fulfil its own mission of providing high-quality assistance services for the benefit of the primary stakeholders (patients and their families) is grounded in capitals that the organisation continuously uses and reproduces. In particular, financial capital is reproduced by agreements with local health agencies and fundraising activities; human capital is reproduced by staff and volunteer recruitment, internal training activities and evaluation and reward practices; organisational capital is reproduced by systematically updating and improving operating procedures and the quality management system.

It is worth underlining that human and organisational capitals are at the core of strategic knowledge management and organisational learning actions.

In order to reproduce financial capital and human capital, it is essential to satisfy the expectations of:

(1) The donors, who are willing to sustain a venture they consider worthy.

(2) The staff, providing professional competences in return for of a positive organisational climate.

(3) The volunteers, willing to satisfy their own philanthropic motivations.

(4) The local health agency, whose satisfaction the continuity of agreements depends on.

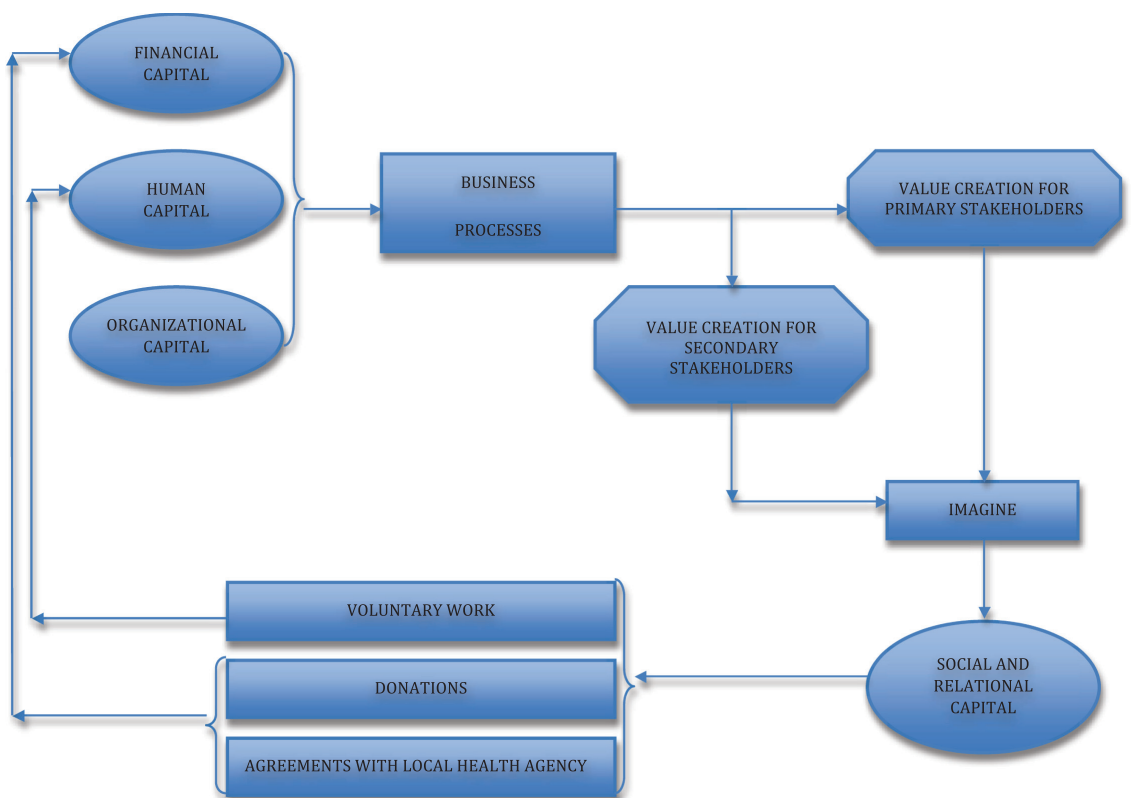

Figure 4.

Interdependence between critical resources, key business processes and stakeholders' satisfaction

Integrated reporting in health organisations 
JIC

22,2

328

Furthermore, meeting the primary and secondary stakeholder expectations confirms GGA as an organisation able to play a positive role in facing widespread and socially relevant needs. It reproduces social and relational capital, improving relations with stakeholders along with its image and reputation. Social and relational capital in turn makes the organisation attractive for primary and secondary stakeholders and strengthens its role and continuity.

This empirical solution supports a third IIRF adjustment.

A3. Reshaping the business processes as suggested by IIRF, including direct, indirect and support processes in the framework (see Figure 5).

This solution leads to the disclosure of GGA's business model, explaining value creation process and the role IC plays in it. In particular, it highlights the relevant capitals, processes, stakeholders, values as well as strategic interdependences and connections between these elements.

As a consequence, the third IIRF adjustment complements the previous ones so that an interpretative framework is triggered that is able to disclose the business processes linking capitals, stakeholders and value creation. The adjusted IIRF then fosters awareness of the organisation's business model, making clear the value creation and the role IC plays in it. In this way, integrated reporting provides a sound basis to enable organisational learning and integrated thinking, as well as proactive management practices.

Table 6 summarises the action research so far. Column 1 describes the GGA disclosure needs, and Column 2 compares them with integrated reporting weaknesses. Column 3 briefly describes the empirical solutions adopted in GGA to accomplish its disclosure needs and Column 4 states the IIRF adjustments. Column 5 relates to theoretical references, and Column 6 links the actions with implications for IC in non-profit healthcare organisations. Implications for IC in non-profit healthcare organisations are discussed in the following section.

Figure 5.

The third adjustment of IIRF: direct, indirect and support processes are introduced into the business model

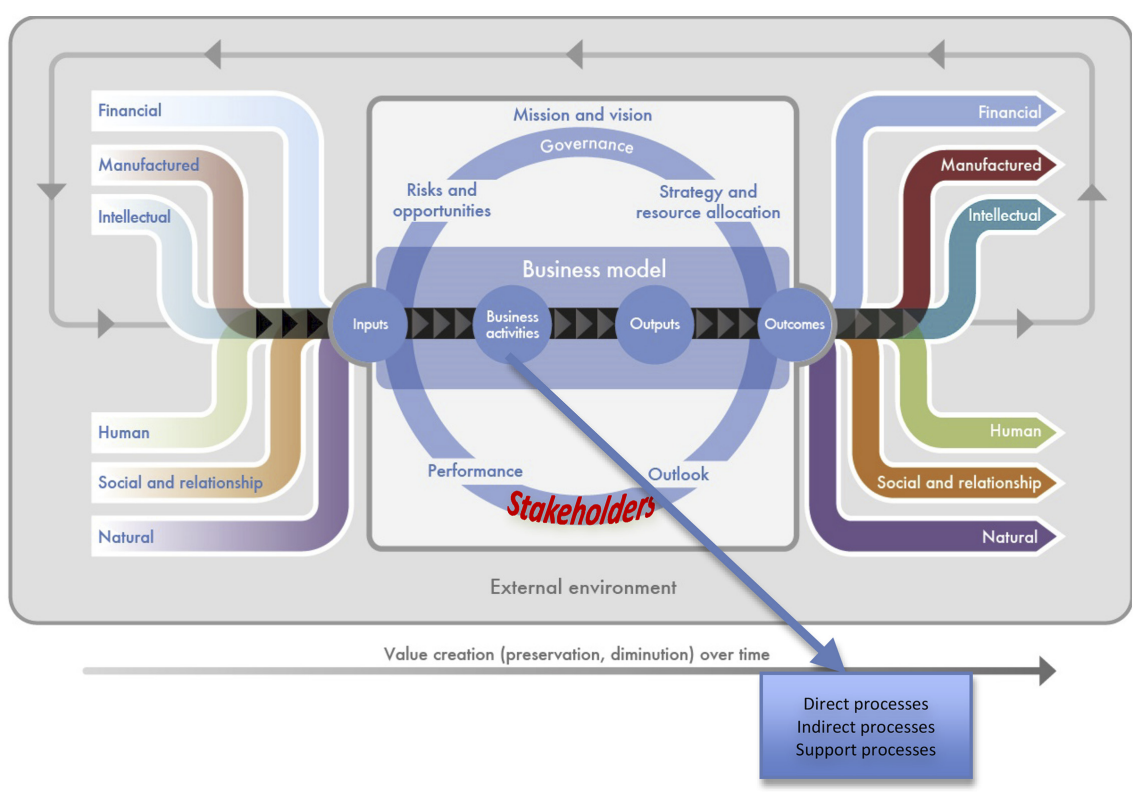




\section{Conclusions, limitations and further works}

The case study presented here proposes a set of adjustments to IIRF that are motivated by the need for a better reporting document able to highlight a healthcare organisation's business model and how IC acts as a strategic lever for value creation (Leal et al., 2019). The suggested adjustments are conceived with the aim to overcome the weaknesses of IIRF as revealed in the extant literature (Garanina and Dumay, 2017; Feng et al., 2017; Dumay and Roslender, 2013; Demartini et al., 2015) as well as by its uncritical implementation in some Italian health organisations. In particular, they foster an integrated reporting, effectively enabling integrated thinking (Guthrie et al., 2017).

Built at the crossroads between an empirical and a theoretical path, the case study was instrumental both to understand the criticalities of the framework and to test the proposed solutions:

(1) The first point addresses the gaps of IIRF in considering the role of primary and secondary stakeholders as beneficiaries of the performance of an organisation; the suggested adjustment consists of extracting stakeholders from relational and social capital and evidencing them as key elements in the business model.

(2) The second point regards the limit of IIRF in considering organisational performance only in terms of capital increases (or decreases), neglecting non-financial outcomes; the proposed adjustment adds to capital increase/decrease answers to stakeholders' needs and expectations, generally considered in health care as the main goals of their activities.

(3) The third point faces the lack of a clear understanding of how business processes create value, both responding to stakeholders' expectations and increasing the organisation's IC; the adjustment redesigns the business activities as suggested by IIRF, introducing direct, indirect and support processes into the framework.

These adjustments are an important step to help healthcare organisations move beyond a standard IIRF tailored to for-profit companies and to give relevance within their specific business models to the links between IC and the outcomes of healthcare processes.

For example, the literature review about IC in healthcare organisations has revealed that healthcare organisations, despite the pivotal importance they give to intangible resources, do not feel the need to explicitly disclose IC. The main reason is that these organisations generally do not consider IC as a comprehensive asset and rather manage single IC components such as staff skills, organisational climate or reputation (Collins and Collins, 2007; Peng et al., 2007; Leal et al., 2019). Nonetheless, the case study shows that the adjusted IIRF is able to support healthcare managers to better understand IC, its role and its value.

The paper also contributes to filling the gap presented by the scarce attention IIRF pays to stakeholders as the framework neglects their role, leaving them within social and relational capital despite research indicating the pivotal role of stakeholders in both profit and nonprofit organisations. This also prevents the creation of an evident link between the organisation's purposes and IC. For healthcare organisations, it negatively affects their perception of the extent that IC contributes to creating value for stakeholders and achieving non-financial outcomes. On the contrary, in health organisations, performance should be considered in a broad sense, especially considering non-financial outcomes, and it is true both in profit and non-profit health organisations (Peng et al., 2007; Lytras and Ordonez de Pablos, 2009; Adams and Simnett, 2011). The adjusted IIRF, giving a specific place to stakeholders in the model, overcomes this limitation (Feng et al., 2017).

Finally, the extant literature shows that health organisations struggle to manage IC in a strategic and comprehensive way (Vishnu and Gupta, 2015; Mazzotta, 2018). IIRF is weak in
Integrated reporting in health organisations 
linking IC to business processes, as they are seen as a "black box" and not explored in detail (Beattie and Smith, 2013; Santis et al, 2019). Thanks to the third adjustment, business processes are better defined in IIRF and are classified as direct, indirect and support processes. This permits the disclosure of IC as a lever to enhance health processes and to help achieve desired outcomes. As processes in healthcare organisations especially involve IC in pursuing intangible outcomes (Schwartz and Pogge, 2000; Covell and Sidani, 2013), it is of paramount importance to disclose IC, processes and outcomes in an integrated way, and this result is achieved by applying the adjusted IIRF (Pirozzi and Ferulano, 2016).

This last adjustment is also important for increasing the internal awareness of managers and physicians about the importance and role of IC (Li et al., 2019). Without a clear and visual framework linking IC with what people concretely do, it was quite impossible for managers to consider IC disclosure something useful (Mouritsen and Roslender, 2009). The empirical evidence arising from the case study confirms the idea that IC disclosure and integrated reporting are relevant not only for external communication but also for internal aims (Inn et al., 2015), creating integrated thinking and supporting health managers in decisions and actions for value creation within organisations.

Therefore, this work contributes to the extant literature about IC in health care, not by suggesting a new IC framework but by proposing an adjusted reporting tool to enhance theoretical contributions previously not considered and to promote effective management practices. The research answers the research questions:

$R Q 1$. Is IIRF able to highlight an organisation's business model and how IC acts as a lever of value creation?

Yes, but adopting some adjustments is necessary to link the crucial components of IC in the healthcare sector with well-described business processes, so as to direct them to the stakeholders' expectations and the mission fulfilment.

$R Q 2$. Can IIRF actually foster integrated thinking and enable proactive management practices?

Yes, adopting the adjustments to highlight the current business model and the value creation drivers, and fosters by this way effective changes in the organisational behaviours.

It is worth underlining that none of the single parts of the adjusted framework is innovative by itself, because it takes advantage of different well known theoretical concepts and models:

(1) The IC Framework from the Scandinavian School;

(2) The Stakeholder Theory from Freeman;

(3) The value creation model in terms of outcome generation embedded in the Value Chain Impact Model;

(4) The business process analysis embedded in the Value Chain Model.

Nevertheless, all together and logically connected in the adjusted IIRF these concepts and models give rise to an innovative solution able to highlight the organisations' business model and provide a believable explanation of the links between IC, stakeholders and value creation.

Moreover the adjusted framework assures a bridge between theory and practice in reporting and disclosure activities being the starting point to improve the knowledge about organisations in several directions.

From the theoretical point of view it assumes organisations as holistic systems made of tangible and intangible resources aiming at creating values for their stakeholders through 
specific business processes. As this explanation of organisations' nature is worth in general, within and outside the health-care sector, for profit and not-for profit organisations, the adjusted Frameworks appears applicable for most organisations and for different purposes: education and consultancy as well as governance and managerial activities.

Conversely, from the practical point of view a deep and shared awareness of the business models fosters knowledge management and organisational learning as well as integrated thinking and proactive management practices enabling better performances.

Moreover the adjusted framework can be the basis for a better disclosure thanks to improved information flows and communication activities towards stakeholders, local communities and public institutions. By this way the organisation's visibility is strengthened making well known its mission and created values and fostering a better integration with the economic and social system.

The main limitation of this work is that it is based on a single case study. On the other hand, its initial purpose was to give empirically viable and theoretically grounded solutions to some criticalities of the original reporting framework. Although the adjusted framework is rooted on more reliable theoretical premises and origins from a case study built on a careful methodological basis, now it has to be widely tested and validated: within and outside the health-care sector and in for profit and not-for profit organisations.

From this point of view, the paper provides a large agenda for research and practice. First of all, healthcare organisations could experience the adjusted framework to test if it addresses their disclosure needs and captures the role IC plays in value creation for stakeholders. Furthermore, in non-profit organisations, where value creation is made up of immaterial outcomes whose links with stakeholders and IC are often fuzzy, the adjusted framework could play an important role in shedding light on these links, giving rise to improved management practices. At last in for-profit organisations whose primary stakeholders are shareholders looking for profitability. In this case disclosing not only the business model and how the organisations affect the six capitals, but also the standing of shareholders and stakeholders within the governance system and how their needs and expectations are addressed the adjusted framework can contribute to shed light on the social role played by these organisations.

\section{References}

Abhayawansa, S., Guthrie, J. and Bernardi, C. (2019), "Intellectual capital accounting in the age of integrated reporting: a commentary", Journal of Intellectual Capital, Vol. 20 No. 1, pp. 2-10, doi: 10.1108/JIC-01-2019-223.

Abhayawansa, S.A. (2014), "A review of guidelines and frameworks on external reporting of intellectual capital", Journal of Intellectual Capital, Vol. 15 No. 1, pp. 100-141.

Adams, S. and Simnett, R. (2011), "Integrated Reporting: an opportunity for Australia's not-for-profit sector", Australian Accounting Review, Vol. 21 No. 3, pp. 292-301.

Adams, C.A. (2015), "The international integrated reporting council: a call to action", Critical Perspectives on Accounting, Vol. 27 No. 1, pp. 23-28.

Badia, F., Dicuonzo, G., Petruzzelli, S. and Dell'Atti, V. (2019), "Integrated reporting in action: mobilizing intellectual capital to improve management and governance practices", Journal of Management and Governance, Vol. 23 No. 2, pp. 299-320.

Beattie, V. and Smith, S.J. (2013), "Value creation and business models: refocusing the intellectual capital debate", The British Accounting Review, Vol. 45 No. 4, pp. 243-254.

Bontis, N. (1998), "Intellectual capital: an exploratory study that develops measures and models", Management Decision, Vol. 36 No. 2, pp. 63-76.

Brooking, A. (1999), Intellectual Capital: Core Asset for the Third Milennium Entreprise, International Thomson Business Press, London. 
Burns, D. (2007), Systemic Action Research: A Strategy for Whole System Change, Policy Press, Bristol.

Camodeca, R., Almici, A. and Sagliaschi, U. (2019), "Strategic information disclosure, integrated reporting and the role of intellectual capital", Journal of Intellectual Capital, Vol. 20 No. 1, pp. 125-143.

Carlucci, D. and Schiuma, G. (2012), "Assessing and managing organizational climate in healthcare organizations: an intellectual capital based perspective", International Journal of Information Systems in the Service Sector (IJISSS), Vol. 4 No. 4, pp. 49-61.

Carr, W. and Kemmis, S. (2003), Becoming Critical: Education Knowledge and Action Research, Falmer Press, Philadelphia.

Cavicchi, C. (2017), "Healthcare sustainability and the role of intellectual capital: evidence from an Italian regional health service", Journal of Intellectual Capital, Vol. 18 No. 3, pp. 544-563.

Cheng, M., Green, W., Conradie, P., Konishi, N. and Romi, A. (2014), "The international integrated reporting framework: key issues and future research opportunities", Journal of International Financial Management and Accounting, Vol. 25 No. 1, pp. 90-119.

Chiucchi, M.S., Giuliani, M. and Marasca, S. (2016), "The rise and fall of IC reporting in Italy: evidence from the field", European Conference on Intellectual Capital, pp. 54-61.

Collins, S.K. and Collins, K.S. (2007), "Succession planning and leadership development: critical business strategies for healthcare organizations", Radiology Management, Vol. 29 No. 1, pp. 16-21.

Covell, C. and Sidani, S. (2013), "Nursing intellectual capital theory: implications for research and practice", Online Journal of Issues in Nursing, Vol. 18 No. 2, p. 2.

Dameri, P. and Girella, L. (2019), "Putting integrated reporting where it was not: the case of the not-forprofit sector", Financial Reporting, Vol. 2020 No. 2, pp. 111-140.

Dameri, R.P. and Ricciardi, F. (2015), "Smart city intellectual capital: an emerging view of territorial systems innovation management”, Journal of Intellectual Capital, Vol. 16 No. 4, pp. 860-887.

Danish Ministry of Science Technology and Innovation (2003), Intellectual Capital Statements-The New Guideline, Ministry of Science Technology and Innovation, Copenhagen.

De Villiers, C. and Marques, A. (2016), "Corporate social responsibility, country-level predispositions, and the consequences of choosing a level of disclosure", Accounting and Business Research, Vol. 46 No. 2, pp. 167-195.

Demartini, P., Cesaroni, F.M., Del Baldo, M. and Paoloni, P. (2015), "Entrepreneurial and renewal capitals as key resources of organisations", Conference Proceedings of the International Scientific Conference, p. 31.

Donna, G. (1992), L'impresa Competitiva. Un Approccio Sistemico, Giuffré, Milano.

Donna, G. (1999), La creazione di valore nella gestione dell'impresa, Carocci, Roma.

Dumay, J. and Garanina, T. (2013), "Intellectual capital research: a critical examination of the third stage”, Journal of Intellectual Capital, Vol. 14 No. 1, pp. 10-25.

Dumay, J. and Roslender, R. (2013), "Utilising narrative to improve the relevance of intellectual capital", Journal of Accounting and Organizational Change, Vol. 9 No. 3, pp. 248-279.

Dumay, J., Bernardi, C., Guthrie, J. and La Torre, M. (2017), "Barriers to implementing the international integrated reporting framework: a contemporary academic perspective", Meditari Accountancy Research, Vol. 25 No. 4, pp. 461-480.

Dumay, J., La Torre, M. and Farneti, F. (2019), "Developing trust through stewardship: implications for intellectual capital, integrated reporting, and the EU Directive 2014/95/EU", Journal of Intellectual Capital, Vol. 20 No. 1, pp. 11-39.

Dumay, J. (2011), "Intellectual capital and strategy development: an interventionist approach”, Vine, Vol. 41 No. 4, pp. 449-465.

Dumay, J. (2016), "A critical reflection on the future of intellectual capital: from reporting to disclosure”, Journal of Intellectual Capital, Vol. 17 No. 1, pp. 168-184. 
Edvinsson, L. and Malone, M.S. (1997), Intellectual Capital, Piatkus, London.

Eisenhardt, K.M. and Graebner, M.E. (2007), "Theory building from cases: opportunities and challenges", Academy of Management Journal, Vol. 50 No. 1, pp. 25-32.

Eisenhardt, K.M. (1989), "Building theories from case study research", Academy of Management Review, Vol. 14 No. 4, pp. 532-550.

Elton, J. and O'Riordan, A. (2016), Healthcare Disrupted: Next Generation Business Models and Strategies, John Wiley \& Sons, Hoboken.

Erickson, G.S. and Rothberg, H.N. (2013), “A strategic approach to knowledge development and protection”, Service Industries Journal, Vol. 33 Nos 13-14, pp. 1402-1416.

Feng, T., Cummings, L. and Tweedie, D. (2017), "Exploring integrated thinking in integrated reportingan exploratory study in Australia", Journal of Intellectual Capital, Vol. 18 No. 2, pp. 330-353.

Ferrando, P.M. (2019), "Integrated reporting e creazione di valore tra profit e non profit. Il caso dell'Associazione Gigi Ghirotti”, Impresa Progetto, Vol. 2, pp. 1-19.

Fincham, R. and Roslender, R. (2003), "Intellectual capital accounting as management fashion: a review and critique", European Accounting Review, Vol. 12 No. 4, pp. 781-795.

Freeman, R.E. (1984), Strategic Management: A Stakeholder Approach, Pitman, Boston.

Galvan, R.S., Martinez, A.B. and Castro, D.G. (2012), "Intellectual capital and knowledge management models within public healthcare organizations", Proceedings of the European Conference on Knowledge Management, ECKM, Vol. 2, pp. 1056-1064.

Garanina, T. and Dumay, J. (2017), "Forward-looking intellectual capital disclosure in IPOs: implications for intellectual capital and integrated reporting", Journal of Intellectual Capital, Vol. 18 No. 1, pp. 128-148.

GECES Social (2014), "Impact measurement SubGroup”, Report adopted, available at: www.febea.org.

Guthrie, J., Manes-Rossi, F. and Orelli, R.L. (2017), "Integrated reporting and integrated thinking in Italian public sector organisations", Meditari Accountancy Research, Vol. 25 No. 4, pp. 553-573.

Hall, R. (1993), "A framework linking intangible resources and capabilities to sustainable competitive advantage", Strategic Management Journal, Vol. 14 No. 8, pp. 607-618.

Harrison, J.S. and Wicks, A.C. (2013), "Stakeholder theory, value, and firm performance", Business Ethics Quarterly, Vol. 23, p. 1 (January 2013).

Hassan, H., Saleh, N.M., Kamaluddin, A. and Hamzah, N. (2015), "The role of leadership on intellectual capital as strategy towards hospitals' performance”, International Conference on Intellectual Capital and Knowledge Management and Organisational Learning, Academic Conferences International, p. 363.

Hehemberger, L., Harling, A.M. and Scholten, P. (2015), "A practical guide to measuring and managing impact”, EVPA, available at: https://evpa.eu.com/.

Hellström, T. (2008), "Transferability and naturalistic generalization: new generalizability concepts for social science or old wine in new bottles?”, Quality and Quantity, Vol. 42 No. 3, pp. 321-337.

Hunt, J.C., Gruenwoldt, E. and Lyster, A.H. (2011), "April). Engaging the next generation of health leaders: perspectives of emerging health leaders", Healthcare Management Forum, Vol. 24 No. 1, pp. 4-8.

Inn, J.T.J., Dumay, J. and Kokubu, K. (2015), "A critical examination of implementing government sponsored intellectual capital management and reporting programs for small and medium enterprises", VINE, Vol. 45 No. 2, p. 214.

International Integrated Reporting Council, IIRC (2016), "What? The tool for a better reporting", available at: https://integratedreporting.org/what-the-tool-for-better-reporting/ (accessed 8 January 2020).

Jakkula, V., Lyly-Yrjänäinen, J. and Suomala, P. (2006), "Challenges of practically relevant management accounting research-the scope and intensity of interventionist research", Paper Presented at 5th New Practices in Management Accounting Research Conference, Brussels.
Integrated reporting in health organisations 
Jönsson, S. and Lukka, K. (2007), "There and back again: doing interventionist research in management accounting", in Chapman, C.S., Hopwood, A.G. and Shields, M.D. (Eds), Handbooks of Management Accounting Research, Elsevier, Oxford, Vol. 1, pp. 373-397.

Korhonen, V. and Paavilainen, E. (2002), "Learning teams and networks: using information Technology as a means of managing work process development in healthcare organizations", Journal for Nurses in Professional Development, Vol. 18 No. 5, pp. 267-273.

Leal, C., Bessa, R., Loureiro, M., Nunes, R. and Marques, C. (2019), "Intellectual capital in healthcare, a social exchange approach", European Conference on Intangibles and Intellectual Capital, Academic Conferences International, pp. 163-XII.

Lewin, K. (1958), Group Decision and Social Change, Holt, Rinehart and Winston, New York.

Li, J., Wu, H., Deng, Z., Lu, N., Evans, R. and Xia, C. (2019), "How professional capital and team heterogeneity affect the demands of online team-based medical service", BMC Medical Informatics and Decision Making, Vol. 19 No. 1, p. 119.

Lytras, M.D. and Ordonez de Pablos, P. (2009), "Managing, measuring and reporting knowledge-based resources in hospitals", International Journal of Technology Management, Vol. 47 Nos 1-3, pp. 96-113.

Mazzotta, R. (2018), "The communication of intellectual capital in healthcare organisations: what is disclosed and how?", International Journal of Knowledge-Based Development, Vol. 9 No. 1, pp. 23-48.

Miller, L.M. (2015), "E-health: knowledge generation, value intangibles, and intellectual capital", International Journal of Healthcare Management, Vol. 8 No. 2, pp. 100-111.

Mouritsen, J. and Roslender, R. (2009), “Critical intellectual capital”, Critical Perspectives on Accounting, Vol. 20 No. 7 , pp. 801-803.

Nahapiet, J. and Ghoshal, S. (1998), "Social capital, intellectual capital, and the organizational advantage", Academy of Management Review, Vol. 23 No. 2, pp. 242-266.

Nonaka, L., Takeuchi, H. and Umemoto, K. (1996), "A theory of organizational knowledge creation”, International Journal of Technology Management, Vol. 11 Nos 7-8, pp. 833-845.

Peng, A.T.J. and Lee, E.Y.S. (2005), "Healthcare intellectual capital: a framework of analysis at the hospital level and the alliance level", in Proceedings of the European Conference on Knowledge Management, pp. 412-420.

Peng, T.J.A., Pike, S. and Roos, G. (2007), "Intellectual capital and performance indicators: Taiwanese healthcare sector", Journal of Intellectual Capital, Vol. 8 No. 3, pp. 538-556.

Pirozzi, M.G. and Ferulano, G.P. (2016), "Intellectual capital and performance measurement in healthcare organizations: an integrated new model”, Journal of Intellectual Capital, Vol. 17 No. 2, pp. 320-350.

Porter, M.E. (1985), Competitive Advantage. Creating and Sustaining Superior Performance, The Free Press, New York.

Radaelli, G., Mura, M., Spiller, N. and Lettieri, E. (2011), "Intellectual capital and knowledge sharing: the mediating role of organisational knowledge-sharing climate", Knowledge Management Research and Practice, Vol. 9 No. 4, pp. 342-352.

Rappaport, A. (1986), Creating Shareholder Value: The New Standard for Business Performance, The Free Press, New York, NY.

Reuter, M. and Messner, M. (2015), "Lobbying on the integrated reporting framework: an analysis of comment letters to the 2011 discussion paper of the IIRC. Accounting", Auditing and Accountability Journal, Vol. 28 No. 3, pp. 365-402.

Robinson, J.C. (1998), "Financial Capital and Intellectual Capital in Physician Practice Management: PPM firms are growing faster than other forms of physician organization. Do they have a financial and competitive advantage?", Health Affairs, Vol. 17 No. 4, pp. 53-74.

Rusconi, G. (2019), "Ethical firm system and stakeholder management theories: a possible convergence", European Management Review, Vol. 16, pp. 147-166. 
Santis, S., Bianchi, M., Incollingo, A. and Bisogno, M. (2019), "Disclosure of intellectual capital components in integrated reporting: an empirical analysis", Sustainability, Vol. 11 No. 1, p. 62.

Schaper, S., Nielsen, C. and Roslender, R. (2017), "Moving from irrelevant intellectual capital (IC) reporting to value-relevant IC disclosures: key learning points from the Danish experience", Journal of Intellectual Capital, Vol. 18 No. 1, pp. 81-101.

Schwartz, R.W. and Pogge, C. (2000), "Physician leadership is essential to the survival of teaching hospitals", The American Journal of Surgery, Vol. 179 No. 6, pp. 462-468.

Serenko, A. and Bontis, N. (2004), "Meta-review of knowledge management and intellectual capital literature: citation impact and research productivity rankings", Knowledge and Process Management, Vol. 11 No. 3, pp. 185-198.

Sibbald, S.L., Wathen, C.N. and Kothari, A. (2016), "An empirically based model for knowledge management in health care organizations", Health Care Management Review, Vol. 41 No. 1, pp. 64-74.

Sorrells-Jones, J. and Weaver, D. (1999), "Knowledge workers and knowledge-intense organizations, part 1: a promising framework for nursing and healthcare", JONA: The Journal of Nursing Administration, Vol. 29 Nos 7/8, pp. 12-18.

Starc, A. (2009), "Nursing professionalism in Slovenia: knowledge, power, and ethics", Nursing Science Quarterly, Vol. 22 No. 4, pp. 371-374.

Scuotto, V., Ferraris, A., Bresciani, S., Al-Mashari, M. and Del Giudice, M. (2016), "Internet of Things: applications and challenges in smart cities. A case study of IBM smart city projects", Business Process Management Journal, Vol. 22 No. 2, pp. 357-367.

Stewart, T.A. (1997), Intellectual Capital: The New Wealth of Organizations, Doubleday, New York.

Stringer, E.T. (2013), Action Research, Sage publications Thousand Oaks, California.

Sukhari, A. and De Villiers, C. (2019), "The influence of integrated reporting on business model and strategy disclosures", Australian Accounting Review, Vol. 29 No. 4, pp. 708-725.

Sveiby, K.E. (1997), The New Organizational Wealth: Managing and Measuring Intangible Assets, Berrett-Koehler., San Francisco.

Teece, D.J. (1998), "Capturing value from knowledge assets: the new economy, markets for know-how, and intangible assets", California Management Review, Vol. 40 No. 3, pp. 55-79.

Terblanche, W. and De Villiers, C. (2019), "The influence of integrated reporting and internationalisation on intellectual capital disclosures", Journal of Intellectual Capital, Vol. 20 No. 1, pp. 40-59.

Thomka, L.A. (2007), "Mentoring and its impact on intellectual capital: through the eyes of the mentee", Nursing Administration Quarterly, Vol. 31 No. 1, pp. 22-26.

Vishnu, S. and Gupta, V.K. (2015), "Performance of intellectual capital in Indian healthcare sector", International Journal of Learning and Intellectual Capital 2, Vol. 12 No. 1, pp. 47-60.

Wong, S.W. and Wickramasinghe, N. (2014), "Applying the principles of KM to effect streamlined healthcare operations: a Malaysian case study", Lean Thinking for Healthcare, Springer, New York, NY, pp. 225-238.

Yin, R.K. (1994), Case Study Research: Design and Methods, Sage Publications, London.

Zambon, S. and Dumay, J. (2016), "A critical reflection on the future of intellectual capital: from reporting to disclosure”, Journal of Intellectual Capital, Vol. 17 No. 1, pp. 168-184.

\section{About the authors}

Renata Paola Dameri is an associate professor in Accounting at the University of Genoa, Department of Economics and Business Studies. Her research interests regard Intellectual capital, Not-for-profit Organizations, Non financial disclosure, Management Information Systems, Smart city and Smart city performance measurement, Innovation, Entrepreneurship and entrepreneurial university, Management and entrepreneurship in the creative and cultural sector. She has published in Journal of Intellectual 
capital, IMA Journal of Managerial Mathematics, Journal of Information Systems, Knowledge Management Research and Practices, Technological Forecasting and Social Changes, Social Science Computer Review. Renata Paola Dameri is the corresponding author and can be contacted at: dameri@ economia.unige.it

Pier Maria Ferrando is a professor in Business Administration at the University of Genoa, Department of Economics and Business studies, and former Dean of the same Department. His research interests regard Intellectual capital, Value creation, Business performance, Non-profit organizations, Non-financial disclosure, Entrepreneurship and entrepreneurial university, Innovative start-ups. He is Editor in chief of the on-line scientific journal ImpresaProgetto - Electronic Journal of Management.

For instructions on how to order reprints of this article, please visit our website: www.emeraldgrouppublishing.com/licensing/reprints.htm Or contact us for further details: permissions@emeraldinsight.com 